Natural history

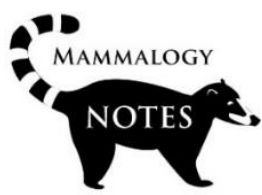

\title{
Differences in body mass among frugivorous bats Artibeus lituratus and Carollia perspicillata (Chirop- tera: Phyllostomidae) from an urban and a peri-urban area of Cúcuta, Colombia
}

\author{
Friedman Pabón ${ }^{\text {(D) }}$, Aldemar A. Acevedo $1,2 *$ (D)
}

1 Grupo de Investigación en Ecología y Biogeografía, Universidad de Pamplona, Pamplona, Colombia.

2 Laboratorio de Biología Evolutiva, Departamento de Ecología, Facultad de Ciencias Biológicas, Pontificia Universidad Católica de Chile

*Correspondence: aeacevedo@uc.cl

\begin{abstract}
We report differences in body mass of two species of fruit bats, Artibeus lituratus and Carollia perspicillata, from two fragments of tropical dry forest (TDF) located in urban and peri-urban areas of the city of Cúcuta, Colombia. From January to September 2018 bat sampling was carried out using mist nets to captured and weigh individuals in the field. The analysis was based only on adults who were not in a reproductive state. We found that both males and females of each species had a higher body mass in the peri-urban area than in the urban area. Our results highlight the importance of testing subsequent hypotheses to explain body mass variations across environmental gradients in response to factors related to diet, diseases, and changes in land use, among others.
\end{abstract}

Palabras clave: Tropical dry Forest, chiropterans, ecology.

\section{Resumen}

Reportamos diferencias en el peso corporal de dos especies de murciélagos frugivoros, Artibeus lituratus y Carollia perspicillata, en dos fragmentos de bosque seco tropical (BST) ubicados en áreas urbanas y periurbanas del municipio de Cúcuta, Colombia. De enero a septiembre de 2018, se realizaron muestreos de murciélagos utilizando redes de niebla, y los individuos capturados se pesaron en el campo. Los datos utilizados en nuestro análisis solo correspondieron a adultos que no estaban en estado reproductivo. Encontramos que tanto hembras como machos de cada especie tenían un mayor peso corporal en el área periurbana que en el área urbana. Nuestros resultados resaltan la importancia de evaluar hipótesis posteriores para explicar las variaciones de peso corporal en gradientes ambientales como respuesta a factores relacionados con la dieta, las enfermedades, y cambios en el uso del suelo, entre otros.

Key words: Bosque seco tropical, quirópteros, ecología. 
Bats are recognized for their ability to respond to ecological changes as a result of their trophic diversity (Jiménez \& Mantilla 2008; Klingbeil \& Willig 2009), making them a vitally important group in the regulation and regeneration of ecosystems, seed dispersal, pest control and pollination (Molina \& Eguiarte 2003; Bumrungsri et al. 2008; Bumrungsri et al. 2009). Due to the high adaptability of many species to environmental change (Medellin et al. 2000), bats are an interesting group to evaluate how different individuals from the same species respond to environmental gradients. Several studies have demonstrated that bats are sensitive to changes in the environment and as a consequence exhibit changes in reproduction, ecology, and development (Soriano \& Ochoa, 2001; Galindo-González 2007; Sherwin et al. 2013; Meyer et al. 2016). These differences vary geographically as the environmental conditions and distribution of resources in transformed landscapes can induce phenotypic differences in wing shape, body, and cranial size, in addition to changes in their behavior (Pérez-Torres \& Ahumada, 2004; Mena 2010; Aguirre \& Barquez 2013; Meyer et al. 2016). Here, we evaluate how the body mass of two species of fruit bats, Artibeus lituratus and Carollia perspicillata, varies in two fragments of tropical dry forest (TDF) located in an urban and a peri-urban area.

From February to September 2018, we carried out eight monthly surveys in two fragments of tropical dry forest (TDF) separated by approximately $8 \mathrm{~km}$ (Figure 1). The first fragment is located in a peri-urban zone in the San Pedro district on the outskirts of the city of Cúcuta (7.804722, -72.525). The fragment comprises an area of $23289 \mathrm{~m}^{2}$ and it is composed of secondary vegetation (e.g. Licania apetala) and some atypical species (e.g. Ficus carica, Solanum lycopersicum). This fragment is generally in good condition, despite of the presence of some rice crops and two human settlements located close to the study area. The second fragment is located at the 'EcoParque' theme park, one of the largest green zones in the urban area of Cúcuta (7.86438, -72.5006). This fragment comprises $20939 \mathrm{~m}^{2}$ of highly perturbed areas and consists largely of shrubby and dry scrub vegetation and small fruit trees such as the 'mamoncillo' Melicoccus bijugatus. It is embedded between residential buildings and recreational areas. Some abandoned surrounding buildings are used as shelters by some species of bats. Following the methodology of Vargas et al. (2006), two mist-nets $(12 \times 2.5 \mathrm{~m}$; mesh of $35 \mathrm{~mm})$ were used between 18:00 to 00:00 and were checked every 15 minutes. At each study site, the mist-nets were located according to vegetation and topography typical of TDF ecosystems. We accumulated 192 mist-net/hours, corresponding to 96 mist-net/hours for each evaluated site.

The identification of the two species of bats was based on morphometric measurements usually used for chiropterans (Díaz et al. 2016); such measurements were taken for each collected individual using a Mitutoyo 530-114BR caliper of $\pm 0.05 \mathrm{~mm} / 0.002$ high precision. The differentiation between individuals of $C$. perspicillata and those of its sympatric species C. brevicauda was based on the lower and upper tooth row length, being smaller in C. brevicauda, as reported by Murillo-Garcia (2014). Moreover, to differentiate A. lituratus from other co-occurring species of the genus (A. jamaicensis and A. planirostris), we followed (Tirira 2007), who indicated the closest way to differentiate these species is by the coloration pattern of $A$. lituratus with the four upper facial stripes wider and more pronounced than the lower ones, as well as its yellowish tragus. All the individuals were weighed within the hour of capture using a $100 \mathrm{~g}$ calibrated digital weight scale with an accuracy of $0.01 \mathrm{~g}$. To avoid weighing the same individual several times, each bat was marked by numerical perforations in the wing membrane (mesopatagium) using the 4 digit X 3/8 "Lhaura ${ }^{\circledR}$ tattoo forceps; each individual was assigned a consecutive number (in case they were recaptured); the individuals were released at the capture site. We captured 
119 adult and non-reproductive bats of $A$. lituratus (periurban= 66; urban= 53) and 77 individuals of C. perspicillata (periurban= 48; urban=29). No individual was recaptured in different field trip visits.
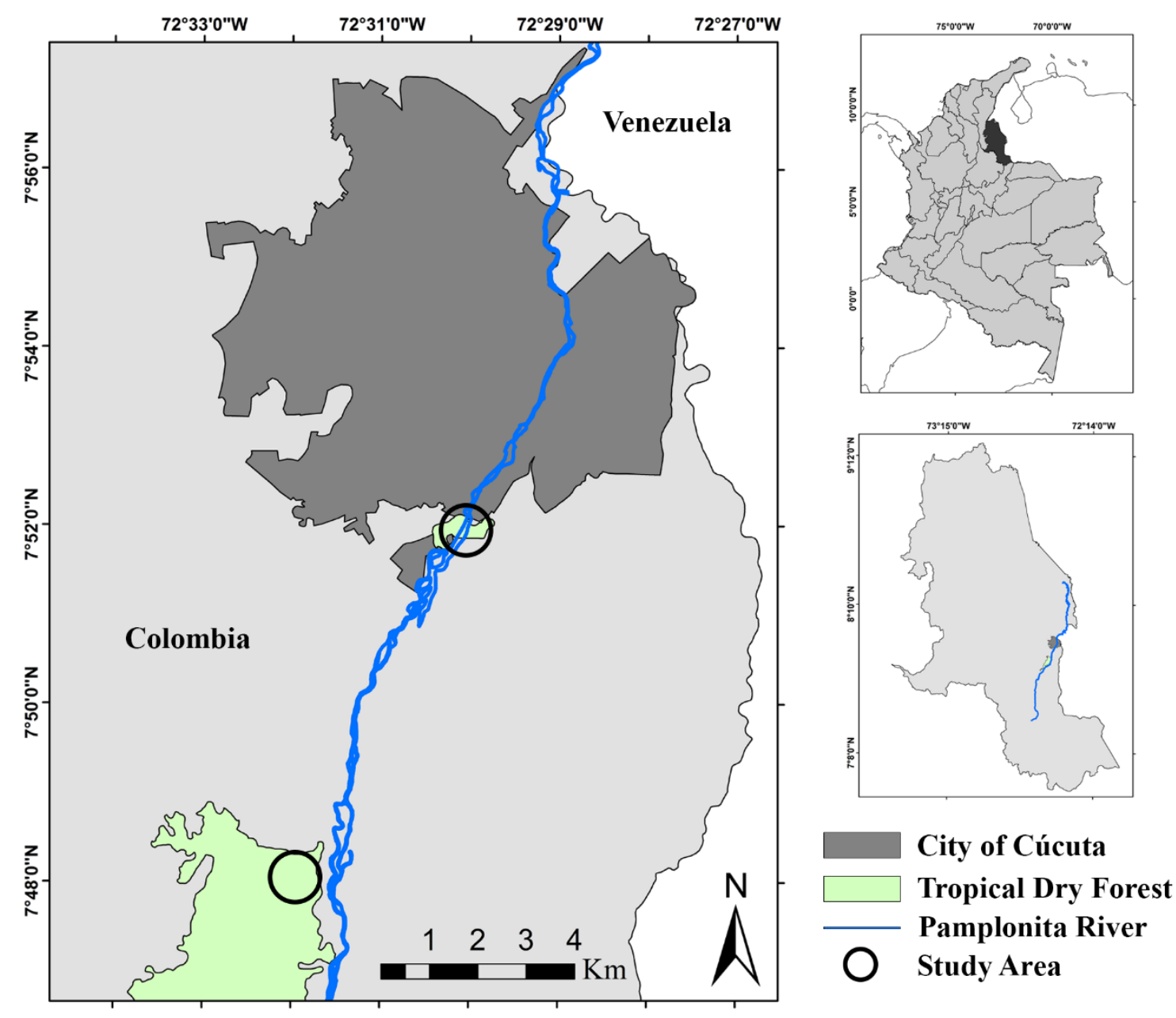

FIGURE 1. Study area in a fragment of Tropical Dry Forest (TDF). Metropolitan area of Cúcuta, Colombia.

The analysis of mass variation among individuals from different patches was based only on adult and non-reproductive individuals. Pregnant and lactating females were identified by the presence of large, dark-colored nipples. Males were classified as reproductive if they had the testes in the scrotal position, or inactive when the testes were abdominal (Tirira 1998). We determined two categories of age (adult and subadult) based on the degree of ossification of the epiphyseal phalanges (Kunz 1988; Santos et al. 2010). We tested body mass differences of A. lituratus and C. perspicillata for each sex between urban and peri-urban areas using the Mann-Whitney U-Test. Five individuals of each species were preserved following the protocols of Simmons \& Voss (2009) and were deposited in the mastozoological collection of the Museum of Natural Sciences 'José Celestino Mutis' of the University of Pamplona, Norte de Santander, Colombia (A. lituratus: MCNUP-M451-456, C. perspicillata: MCNUP-M457-462). 
Our results show that the individuals of both males and females of $A$. lituratus and $C$. perspicillata from different fragments present significant differences in body mass (Figure 2, Table 1), with a tendency for individuals of greater body mass to be in the peri-urban TDF (Figure 2, Table 1). Our results agree with previous studies that have documented that better habitat quality and functional connectivity positively influence the body mass of $A$. lituratus (Chacón \& Ballesteros 2019). On the other hand, our body mass records of $A$. lituratus in the urban TDF are lower than those reported by other studies (Davis 1984; Saldaña \& Schondube 2016), while in the peri-urban zones body mass records were slightly higher compared to those reported by Chacón \& Ballesteros (2019). Moreover, our body mass records for $C$. perspicillata in the peri-urban and urban TDF are higher than those reported by Barros et al. 2014. However, Montoya-Bustamante et al. (2016) reported similar body mass values for C. perspicillata in TDF fragments from Valle del Cauca in Colombia.

\section{Artibeus lituratus - Females}

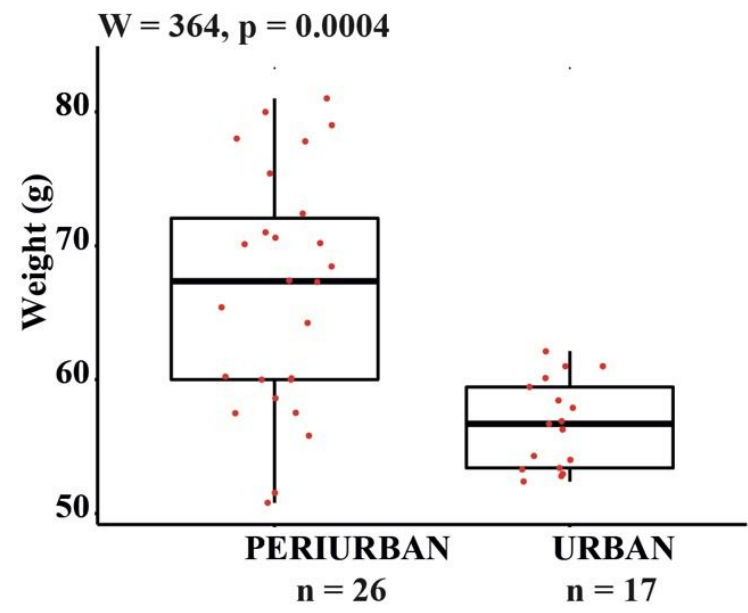

\section{Carollia perspicillata - Females}

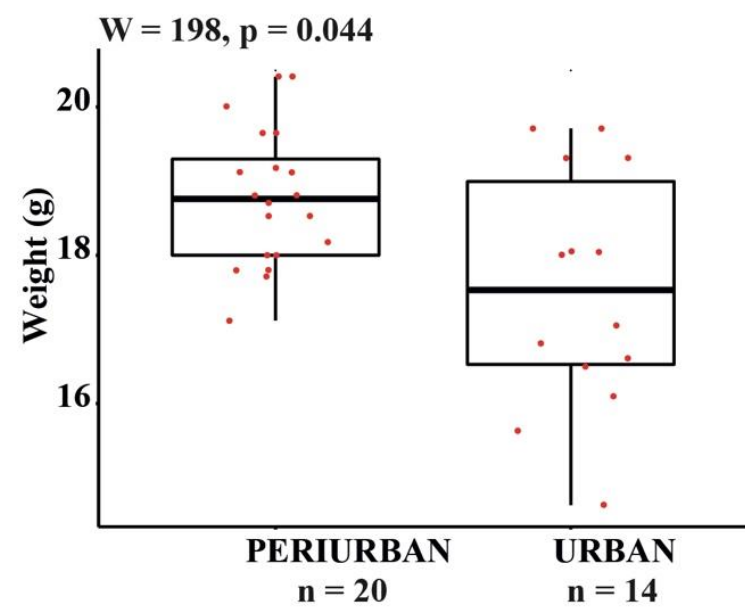

Artibeus lituratus - Males

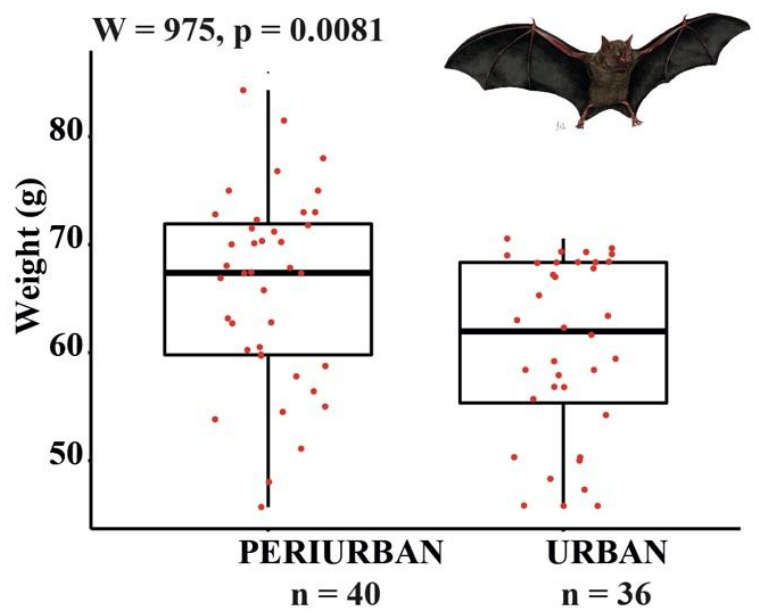

Carollia perspicillata - Males

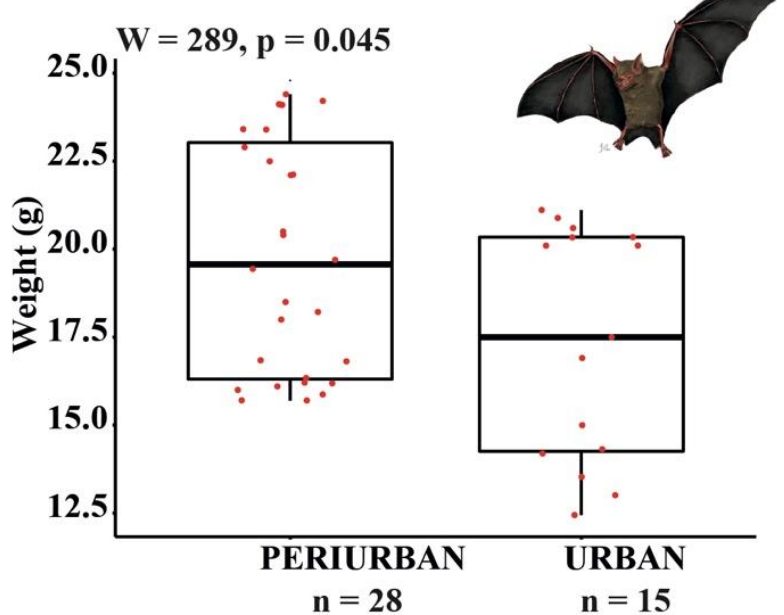

FIGURE 2. Boxplot with confidence intervals of the median weight difference within each species of Artibeus lituratus and Carollia pespicillata. 
Table 1. Mean and standard deviation of body mass (g).

\begin{tabular}{lllll}
\hline Species & Periurban (female) & Urban (female) & Periurban (male) & Urban (male) \\
\hline A. lituratus & $66.6 \pm 8.8(50.8-81)$ & $56.7 \pm 3.2(52.4-62.1)$ & $65.9 \pm 8.9(45.7-84.3)$ & $60.5 \pm 8.2(45.8-70.6)$ \\
C. perspicillata & $18.8 \pm 0.9(17.1-20.4)$ & $17.5 \pm 1.6(14.6-19.7)$ & $19.8 \pm 3.2(15.7-24.4)$ & $17.4 \pm 3.3(12.4-21.1)$
\end{tabular}

It is necessary to test the importance of different environmental factors driving variations in body mass reported in this note. For example, it is necessary to determine the importance of dietary variations, different feeding strategies and habitat use driving consumption patterns and thus individuals body mass. This has been documented for $C$. perspicillata, showing differences in consumption between sexes throughout the year and differential consumption of plant species (Alviz \& Pérez-Torres 2020). Other aspects may relate to the efficient assimilation of nutrients from fruits eaten during the night, which has been associated with variations in body mass (e.g. Artibeus planirostris, Azeredo et al. 2019). In addition, changes in body mass may be associated with species' sensitivity to fragmentation (e.g. Farneda et al. 2015). Similarly, further studies are needed to identify the prevalence of diseases in disturbed habitats that can decrease health status and affect individuals' body mass (e.g. Guerrero et al. 2018). Finally, we highlight the importance of increasing ecological and natural history studies that evaluate changes in the body mass patterns of bat species in urban and peri-urban areas.

\section{ACKNOWLEDGEMENTS}

We thank the Biology program, the Vice-chancellor of Research, and the research group in Ecology and Biogeography at the University of Pamplona for their support. To the staff of the Museo José Celestino and its director José Sierra for the support provided in the curatorship of bat specimens. Special thanks to Jenner Anderson Pabón Peñaloza, for making the bat illustrations. To IdeaWild for donating equipment. Special thanks to the staff of the Ecoparque Comfanorte of Cúcuta. Thanks to Orlando Armesto and Harold Cristancho for their assistance on field trips. We appreciate the feedback offered by Liliana Solano.

\section{REFERENCES}

Aguirre L, Barquez R. 2013. Critical areas for bat conservation: Latin American conservationists build a grand strategy. Bats 31(1):10-12.

Alviz A, Pérez-Torres J. 2020. A difference between sexes: temporal variation in the diet of Carollia perspicillata (Chiroptera, Phyllostomidae) at the Macaregua cave, Santander (Colombia). Animal Biodiversity and Conservation 43(1): 27-35.

https:// doi.org/10.32800/abc.2020.43.0027

Azeredo MM, Ximenes MS, Pereira KA, Fracasso MPA, Lopez LS. 2019. Body mass index and glucose variations during the night in free-ranging Artibeus planirostris (Chiroptera: Phyllostomidae). Zoologia (Curitiba) 36:e28027. https:// doi.org/10.3897/zoologia.36.e28027

Barros LA, Fortes R, Lorini ML. 2014. The Application of Bergmann's Rule to Carollia perspicillata Linnaeus 1758 (Mammalia, Chiroptera). Chiroptera Neotropical 20:1243-1251. 
Bumrungsri S, Harbit A, Benzie C, Carmouche K, Sridith K, Racey P. 2008. The pollination ecology of two species of Parkia (Mimosaceae) in southern Thailand. Journal of Tropical Ecology 24(5):467-475. https:// doi.org/10.1017/S0266467408005191

Bumrungsri S, Sripaoraya E, Chongsiri T, Sridith K, Racey P. 2009. The pollination ecology of durian (Durio zibethinus, Bombacaceae) in southern Thailand. Journal of Tropical Ecology 25(1):8592. https://doi.org/10.1017/S0266467408005531

Chacón JJ, Ballesteros J. 2019. Mejor condición corporal de Artibeus lituratus en fragmentos de bosque seco asociados a sistemas silvopastoriles que en sistemas convencionales de ganadería en Córdoba, Colombia. Oecologia Australis 23(3):589-605. https:// doi.org/10.4257/ oeco.2019.2303.16

Davis WB. 1984. Review of the Large Fruit-eating Bats of the Artibeus "lituratus" Complex (Chiroptera: Phillostomatiae) in Middle America. Texas Tech University Press 93:1-16.

Díaz MM, Solari S, Aguirre LF, Aguiar LMS, Barquez RM. 2016. Clave de identificación de los murciélagos de Sudamérica. Tucuman: Publicación Especial № 2, PCMA (Programa de Conservación de los Murciélagos de Argentina). 160 pp.

Farneda FZ, Rocha R, López BA, Groenenberg M, Silva I, Palmeirim JM, Meyer CF. 2015. Trait-related responses to habitat fragmentation in Amazonian bats. Journal of Applied Ecology 52(5):1381-1391. https:// doi.org/10.1111/1365-2664.12490

Galindo-González J. 2007. Efectos de la fragmentación del paisaje sobre poblaciones de mamíferos; el caso de los murciélagos de los Tuxtlas, Veracruz. In: Sánchez-Rojas G, Rojas-Martínez A, editors. Tópicos en sistemática, biogeografia, ecología y conservación de mamíferos. Instituto de Ciencias básicas e ingeniería, Universidad autónoma del estado de Hidalgo, México, D.F. p. 97-114.

Guerrero CAL, Rivera RD, Rojas DV, Triana LC, Niño CA. 2018. Metabolic cost of acute phase response in the frugivorous bat, Artibeus lituratus. Mammal Research 63 (4):397-404. https:// doi.org/10.1007/s13364-018-0375-z

Jiménez A, Mantilla H. 2008. El papel de la tala selectiva en la conservación de bosques neotropicales y la utilidad de los murciélagos como bioindicadores de disturbio. Revista Institucional Universidad Tecnológica Chocó 108. http:/ / dx.doi.org/10.18636/ biodesarrollo.v27i1.441

Klingbeil BT, Willig MR. 2009. Guild-specific responses of bats to landscape composition and configuration in fragmented Amazonian rainforest. Journal of Applied Ecology 46(1):203-213. https:// doi.org/10.1111/j.1365-2664.2008.01594.x

Kunz TH, Kurta A. 1988. Capture methods and holding devices. In: Kunz TH, editors. Ecological and behavioral methods for the study of bats. Smithsonian Institution Press, Washington, D.C. p. $1-29$.

Medellín RA, Equihua M, Amin MA. 2000. Bat diversity and abundance as indicators of disturbance in Neotropical rainforests. Conservation biology 14(6):1666-1675. https:// doi.org/10.1111/j.1523-1739.2000.99068.x

Mena JL. 2010. Respuestas de los murciélagos a la fragmentación del bosque en Pozuzo, Perú. Revista Peruana de Biología 17(3):277-284. https:/ / doi.org/10.15381/rpb.v17i3.2

Meyer CFJ, Struebig MJ, Willig MR. 2016. Responses of Tropical Bats to Habitat Fragmentation, Logging, and Deforestation. In: Voigt CC, Kingston T, editor. Bats in the Anthropocene: Conservation 
of Bats in a Changing World. Cham, Germany: Springer International Publishing. p. 63-103. https:// doi.org/10.1007/978-3-319-25220-9

Montoya-Bustamante S, Rojas-Díaz V, Torres-González AM. 2016. Interactions between frugivorous bats (Chiroptera: Phyllostomidae) and Piper tuberculatum (Piperaceae) in a tropical dry forest in Valle del Cauca, Colombia. Revista de Biología Tropical 64(2):701-713. https:// doi.org/10.15517/RBT.V6412.20689

Molina F, Eguiarte LE. 2003. The pollination biology of two paniculate agaves (Agavaceae) from northwestern Mexico: contrasting roles of bats as pollinators. American Journal of Botany 90(7):1016-1024. https://doi.org/10.3732/ajb.90.7.1016

Murillo-García OE. 2014. Murciélagos de cola corta (Carollia: Phyllostomidae) del Parque Nacional Natural Gorgona (Colombia) y sus implicaciones biogeográficas. Revista de Biología Tropical 62(1):435-445. https:// doi.org/10.15517/ rbt.v62i0.16370

Pérez-Torres J, Ahumada JA. 2004. Murciélagos en bosques alto-andinos, fragmentados y continuos, en el sector occidental de la sabana de Bogotá (Colombia). Universitas Scientiarum 9(1):3346. http:/ / hdl.handle.net/10554/31693

Saldaña VRA, Schondube JE. 2016. La masa corporal explica la dominancia de Artibeus (Phyllostomidae) en ambientes urbanos. In: Ramírez-Bautista A, Pineda-López R, editor. Memorias en Extenso del I Congreso de Fauna Nativa en Medios Antropizados. CONACYTUAQ, México. p. 23-33.

Santos A, García JL, Rodríguez A. 2010. Ecology and reproduction of the bat Centurio senex (Chiroptera: Phyllostomidae) in Oaxaca, Mexico. Revista mexicana de biodiversidad 81(3):847-852. http://dx.doi.org/10.22201/ib.20078706e.2010.003.654

Sherwin HA, Montgomery WI, Lundy MG. 2013. The impact and implications of climate change for bats. Mammal Review 43(3):171-182. https:// doi.org/10.1111/j.1365-2907.2012.00214.x

Simmons NB, Voss RS. 2009. Collection, preparation, and fixation of specimens and tissues. In: Kunz TH, Parsons S, editors. Ecological and behavioral methods for the study of bats. 2nd ed. Johns Hopkins University Press. Baltimore.

Soriano PJ, Ochoa JG. 2001. The consequences of timber exploitation for bat communities in tropical America. In: Fimbel RA, Grajal A, Robinson J, editors. The cutting edge: conserving wildlife in logged tropical forests. Columbia University Press, New York. p. 153-166.

Tirira D. 1998. Memorias del Seminario - Taller: Biología, sistemática y conservación de los Mamíferosdel Ecuador. Museo de Zoología. Centro de Biodiversidad y Ambiente. Pontificia Universidad Católica del Ecuador. Publicación especial I. Quito.

Tirira D. 2007. Mamíferos del Ecuador. Guía de campo. Ediciones Murciélago Blanco. Publicación Especial de los Mamíferos del Ecuador 6. Quito.

Editor: Diego J. Lizcano Received 2020-05-29

Revised 2020-06-15

Accepted 2020-08-28

Published 2020-12-06 